Milan Kragović*, Aleksandra Daković, Marija Marković, Anđela Petković

Institute for technology of nuclear and other mineral raw materials, Belgrade, Serbia
Scientific paper

ISSN 0351-9465, E-ISSN 2466-2585

UDC:620.193.8.94

doi:10.5937/ZasMat1604559K

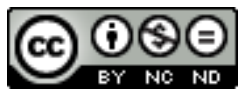

Zastita Materijala 57 (4)

$559-564(2016)$

\title{
Kinetic of thermal degradation of alginate-zeolite composites
}

\begin{abstract}
In this work, natural and Fe(III)-modified zeolte were tested as additives for alginate in order to improve its thermal and pyrolytic properties. For that purpose the natural zeolite (NZA) and Fe(III)modified zeolite coated with alginate $(F e A)$ were used. Thermal degradation of the samples was investigated by using thermal analytic techniques, thermogravimetric (TG) and differential thermal analysis (DTA). The samples were heated from $25^{\circ} \mathrm{C}$ to $1000^{\circ} \mathrm{C}$ at different heating rates (from 5 to $20^{\circ} \mathrm{C}$ ). From experimental results, thermal degradation of the sodium alginate could be clearly separated into several stages based on the weight loss and the weight loss rate. The kinetic parameters (activation energy and pre-exponential factor) for the main degradation phase (from 180 to $500^{\circ} \mathrm{C}$ ) thus were estimated by using the pseudo first-order assumption. The results showed that used zeolites affected the thermal properties of the alginate and reduce activation energy required for pyrolysis from $87.30 \mathrm{~kJ} / \mathrm{mol}$ for pure alginate to $72.75 \mathrm{~kJ} / \mathrm{mol}$ for $\mathrm{NZA}$ and $63.35 \mathrm{~kJ} / \mathrm{mol}$ for FeA. These pyrolysis investigations can be useful for better understanding the thermal stability of these alginate biocomposites and provide necessary information for thermally processing wastes from these biodegradable materials.
\end{abstract}

Keywords: Na-alginate, natural zeolite, Fe(III)-modified zeolite, composite, thermogravimetric and differential thermal analysis, thermal degradation kinetic.

\section{INTRODUCTION}

Nowadays plastics are very often used due to their durability, versatility as well as low price. Using of plastic products give a lot of benefits to humans and modern society in terms of economic activity, jobs and quality of life. Even more, plastics can reduce energy consumption and greenhouse gas emissions in many circumstances, even in some packaging applications when compared to the alternatives. On the other side, plastic is usually non-biodegradable and therefore can remain as waste in the environment for a very long time, it may pose risks to human health as well as the environment and also it can be difficult to reuse and/or recycle in practice [1]. From that point, developing of the new recycle techniques or degradable polymers is economic and environmental necessity. One of possible ways for solving the environmental problems caused by the massive

\footnotetext{
${ }^{*}$ Corresponding author: Milan Kragović

E-mail: m.kragovic@itnms.ac.rs

Paper received: 12. 10. 2016.

Paper accepted: 09. 11. 2016.

Paper is available on the website: www.idk.org.rs/journal
}

use of synthetic polymer materials and their wastes is developing materials based on biopolymers as well as extending their use [2].

Alginate is a naturally occurring polysaccharide obtained from marine brown algae, comprising

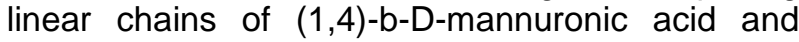
$(1,3)$-a-L-guluronic acid. Sodium alginate is a polyelectrolyte and it is biodegradable and non-toxic polymer, with gelation and high water absorption properties. It has rigid molecular structure, and has been extensively studied on many potential applications in medicine, pharmacy, in food industry or for environmental protection in terms of removal of heavy metals from contaminated waters $[3,4]$. Also, alginate possesses good film forming ability. Hence, it could be used for food packing as a replacement of conventional synthetic polymers.

One of possible ways for recycling and for avoiding huge accumulation of plastic wastes obtained from packing industry is thermal pyrolysis which may provide a sustainable way of recycling organic wastes. This technique offers the possibility of transforming packing wasters into fuel oils for the petrochemical industries or decomposing these wastes for thermal power generation $[5,6]$.

However, the low thermal conductivity of plastics as well as the endothermic character of the 
decomposition reactions involves high power consumption in the pyrolysis process. Using of the additives may permit decrease of the temperature of the process and also could provide a narrower product distribution, which allows control of the type of products obtained with a lower production cost [7]. According to the literature [8], zeolites may act as catalysts in the cracking of polymers, making their transformation into fuel products easier. On the other side, in our previous paper [9] composites of the zeolite-clinoptilolite and alginate (natural (NZA) or Fe(III)-modified zeolite (FeA)) were tested as adsorbents for removal of lead ions from contaminated water solutions. Results obtained for the highest investigated initial concentration of lead $\left(15.1 \mathrm{mmol} / \mathrm{dm}^{3}\right)$ showed good adsorption capacities and maximum adsorbed amounts of lead were 0.50 and $0.66 \mathrm{mmol} / \mathrm{dm}^{3}$ for NZA and $\mathrm{FeA}$, respectively. Also during adsorption process there was no water turbidity what is beside good adsorption properties very important for experiments in column and application under real conditions. Thus, in this work, thermal degradation of the samples used for adsorption experiments (NZA and FeA) was performed and results were compared with those obtained for pure sodium alginate. The aim was to investigate the influence of the natural and $\mathrm{Fe}$ (III)-modified zeoliteclinoptilolite on thermal degradation and pyrolytic properties of the alginate, i.e. indication whether natural and $\mathrm{Fe}(\mathrm{III})$-modified zeolite can be used as additives for thermal decomposition of the alginate.

\section{EXPERIMENTAL}

Chemicals used in this study were of high purity and supplied from Sigma Aldrich Germany.
The natural zeolite-clinoptilolite from Serbia with a particle size $<0.043 \mathrm{~mm}$ (NZ) was used as a starting material. The Fe(III)-modified zeolite (FeZ) was obtained combining the method for the goethite preparation and that for the preparation of Fe-coated zeolite [10,11], and detailed procedure is given elsewhere [12].

Natural and $\mathrm{Fe}(\mathrm{III})$-modified zeolite-alginate composites were prepared using a method described by Yuan and Viraraghavan [13]. A $2 g$ of Na-alginate was dissolved in $100 \mathrm{~cm}^{3}$ of distillated water and then agitated for $24 \mathrm{~h}$. Then, $10 \mathrm{~g}$ of the $\mathrm{NZ}$ or $\mathrm{FeZ}$ was blended with $\mathrm{Na}$-alginate solution for $2 \mathrm{~h}$. Mixed solution was dropped into $0.1 \mathrm{~mol} / \mathrm{dm}^{3}$ of $\mathrm{CaCl}_{2}$ solution. The beads were obtained and hardened by placing them in $2 \%$ solution of $\mathrm{CaCl}_{2}$ for $24 \mathrm{~h}$. Then, beads were 5 times washed with distillated water by agitation at $100 \mathrm{rpm}$ for $30 \mathrm{~min}$. At the end, beads were dried at room temperature. Finally, the NZA (natural zeolite-alginate) and FeA (Fe(III)-modified-alginate beads) were obtained.

Thermal behaviour of the composite samples was followed by differential thermal analysis (DTA) on a Netzsch STA 409 EP. To compare results, DTA and thermogravimetric analysis (TGA) were performed on Na-alginate. Samples were heated from 25 to $1000^{\circ} \mathrm{C}$ in an air atmosphere at heating rates of $5,10,15$ and $20^{\circ} \mathrm{C} / \mathrm{min}$. The samples were kept in a desiccator at a relative humidity of $23 \%$, prior to analyses.

\section{RESULTS AND DISCUSSION}

Figure 1 shows the DTA/TGA curves of the pure Na-alginate heated at $5^{\circ} \mathrm{C} / \mathrm{min}$ up to $1000^{\circ} \mathrm{C}$.

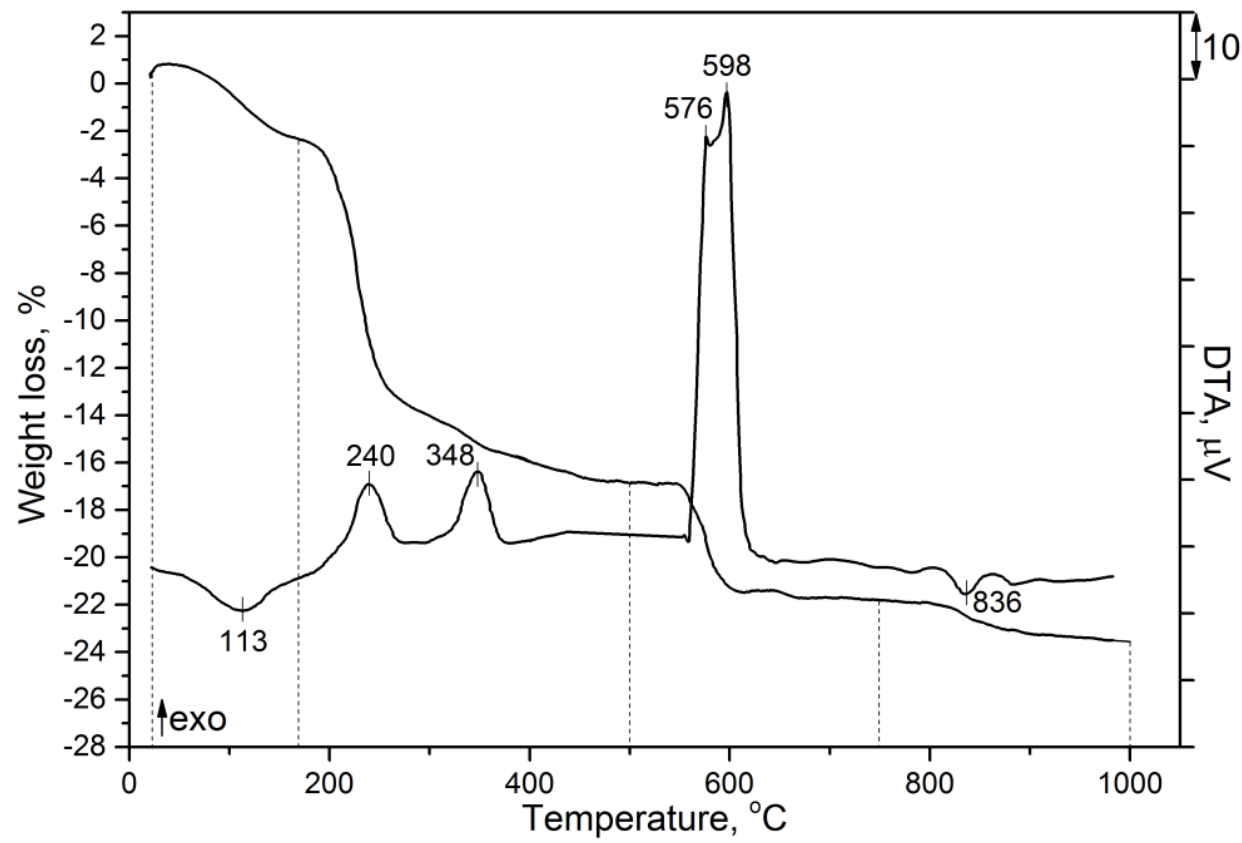

Figure 1 - TGA and DTA curve of the pure Na-alginate at heating rate of $5^{\circ} \mathrm{C} / \mathrm{min}$. 
As can be seen, DTA graph of $\mathrm{Na}$-alginate shows sixth distinct peaks. An endothermic DTA peak at $113^{\circ} \mathrm{C}$ is due to dehydration, and due to this process at TGA curve a mass loss of about $15 \%$ was noted in temperature interval $25-180^{\circ} \mathrm{C}$. The major degradation of $\mathrm{Na}$-alginate occurred in second temperature interval from 180 to $500^{\circ} \mathrm{C}$ (weight loss of about $50 \%$ ) where loss of volatile components, rupture of chains and fragmentation of sodium alginate occurs. This process is followed with two exothermic peaks at DTA curve with maximums at 240 and $348^{\circ} \mathrm{C}$. [14, 15]. Decomposition of $\mathrm{Na}$-alginate and its fragmentation into monomers occurred in third temperature interval form 500 to $700^{\circ} \mathrm{C}$ and this process was followed with exothermic peaks with maximums at 576 and $598^{\circ} \mathrm{C}$ and with the weight loss of about $17 \%$. These processes are followed by fragments and monomer units conversion into carbonate as a by-product. Finally due to oxidation of the carbonate, endothermic peak with minimum at $817^{\circ} \mathrm{C}$ and mass loss of $\sim 6 \%$ was occurred in the temperature interval form 700 to $1000^{\circ} \mathrm{C}[16,17]$. From Figure 1 it is clear that processes occurred in the temperature interval from 180 to $700^{\circ} \mathrm{C}$ are exothermic, indicating that energy released from burning or forming new chemical bonds was greater than the energy absorbed for bond scission during decomposition. That excess between released and activation energy may be collected and used for other energy applications. In order to investigate influence of the zeolites on activation energy for thermal degradation of the alginate, thermal decomposition kinetic was followed for $\mathrm{NZA}, \mathrm{FeA}$ and $\mathrm{Na}$-alginate and results obtained with differential thermal analysis (DTA) at four different heating rates $\left(5,10,15\right.$ and $\left.20^{\circ} \mathrm{C} / \mathrm{min}\right)$ are shown at Figure 2.
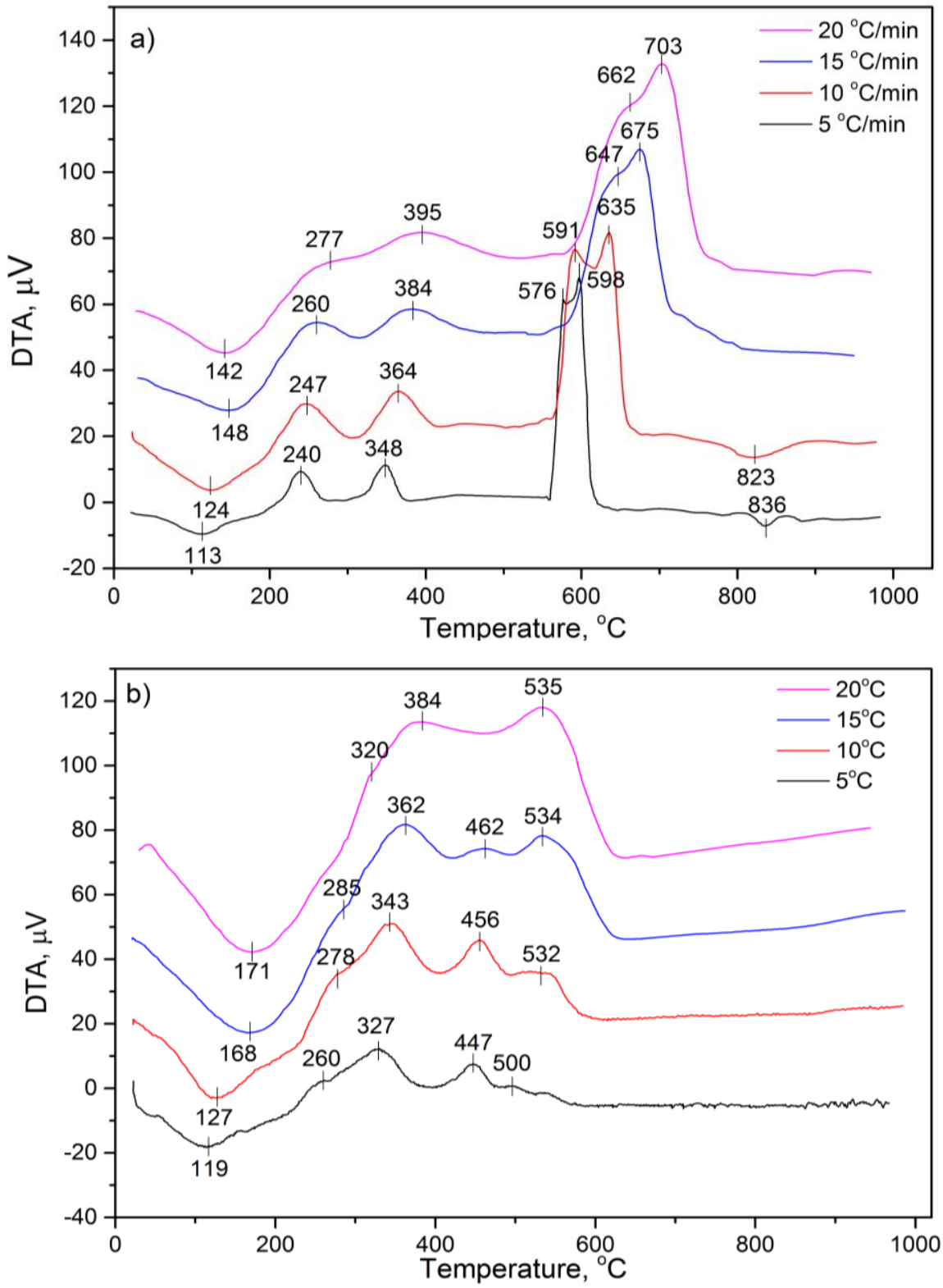


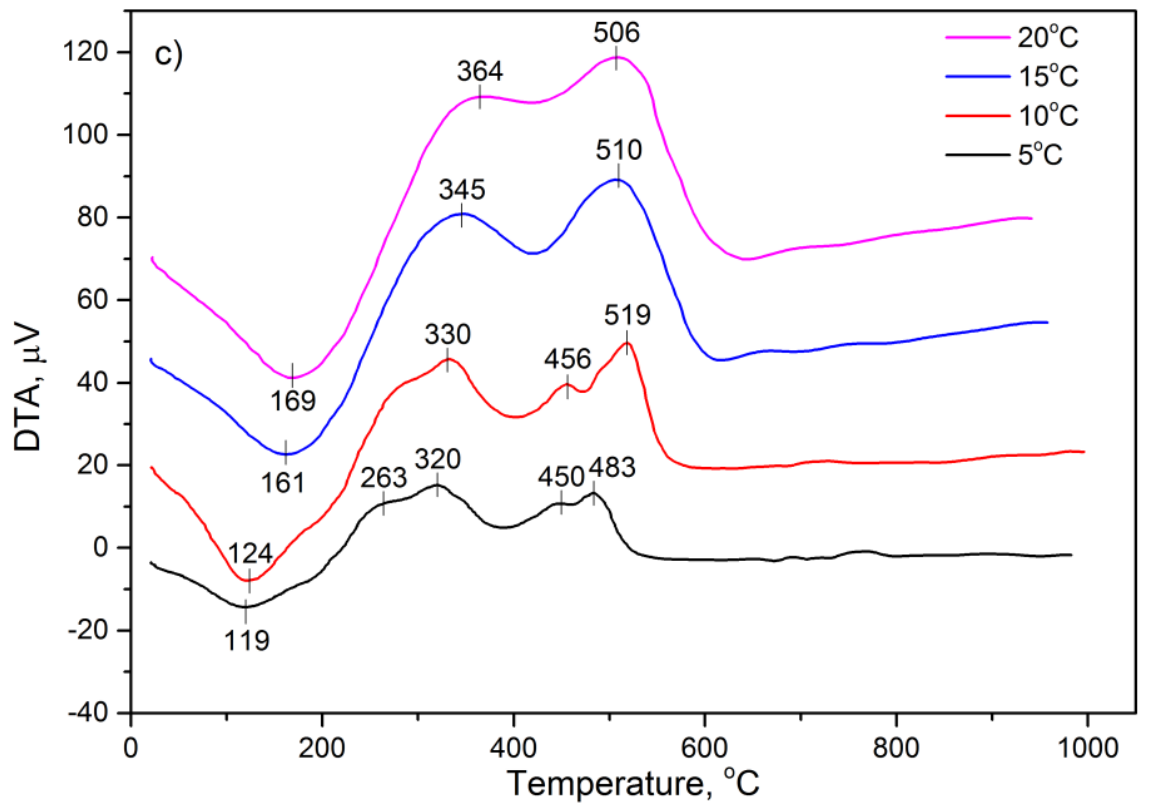

Figure 2 - Influence of the heating rate on the DTA curve for: a) Na-alginate, b) NZA c) FeA.

Since the main weight loss (the highest part of alginate burned) was observed in temperature interval from 180 to $500^{\circ} \mathrm{C} \quad(\sim 50 \%)$, kinetic calculations were performed for most clearly expressed peak at DTA curve in that temperature range (Figure 1, DTA peak at $348^{\circ} \mathrm{C}$ ).

As it can be seen from Figure 2 for all three samples as the heating rate increased the peak of interest became wider and decomposition temperature shifts to the higher values (in DTA diagrams, for $\mathrm{Na}$-alginate from 348 to $395^{\circ} \mathrm{C}$, NZA from 327 to $384^{\circ} \mathrm{C}$ and for FeA from 320 to $364^{\circ} \mathrm{C}$ at heating rate $5^{\circ} \mathrm{C}$ and $20^{\circ} \mathrm{C}$, respectively). It is very important to notice for composite samples, for the same heating rate, the peak temperatures were lower in comparison with $\mathrm{Na}$-alginate, and also, slightly lower temperatures were observed for $\mathrm{FeA}$ than for NZA.

Kinetic parameters, activation energy $\left(E_{a}\right)$ and pre-exponential factor (A) for the thermal decomposition of the samples are determined from data obtained by DTA analysis using the Kissinger method [18]. According to Kissinger method thermal decomposition of sample can be described with following first order kinetic equation:

$$
\left(\frac{\partial x}{\partial t}\right)=k_{T}(1-x)
$$

where, $x$ is the fraction of material decomposed. The magnitude of the rate constant, $\mathrm{k}_{\mathrm{T}}$, can be determined by the temperature and is given by the Arrhenius equation:

$$
k_{T}=A e^{-\frac{E_{a}}{R T}}
$$

where $R$ is gas constant and $T$ is the Kelvin temperature. Following this method, the relationship between the heating rate $(\beta)$ and the peak temperature $(T)$ can be plotted. Obtained results given in Figure 3 showed that the $\ln \left(\beta / \mathrm{T}_{\mathrm{p}}{ }^{2}\right)$ against $1 / T$ are straight lines for all samples $\left(R^{2}>0.95\right)$, indicating that the kinetic mechanism of thermal decomposition of these compounds followed the first order kinetics. The activation energy was determined from slope of the lines (the slope is equal to $-E_{a} / R$ ), while the pre-exponential factor $\ln (A)$ was calculated from the following equation [19]:

$$
A=\beta\left(\frac{E_{\mathrm{a}}}{R T_{p}^{2}}\right) \exp \left(\frac{E_{\mathrm{a}}}{R T_{p}}\right)
$$

and results are listed in Table 1.

Table 1 - Results obtained by Kissinger method

\begin{tabular}{|l|c|c|}
\hline & $\ln (\mathrm{A}), \mathrm{min}^{-1}$ & $\mathrm{E}_{\mathrm{a}}, \mathrm{kJ} / \mathrm{mol}$ \\
\hline Na-alginate & 15.16 & 87.30 \\
\hline NZA & 12.57 & 72.75 \\
\hline $\mathrm{FeA}$ & 10.96 & 63.35 \\
\hline
\end{tabular}




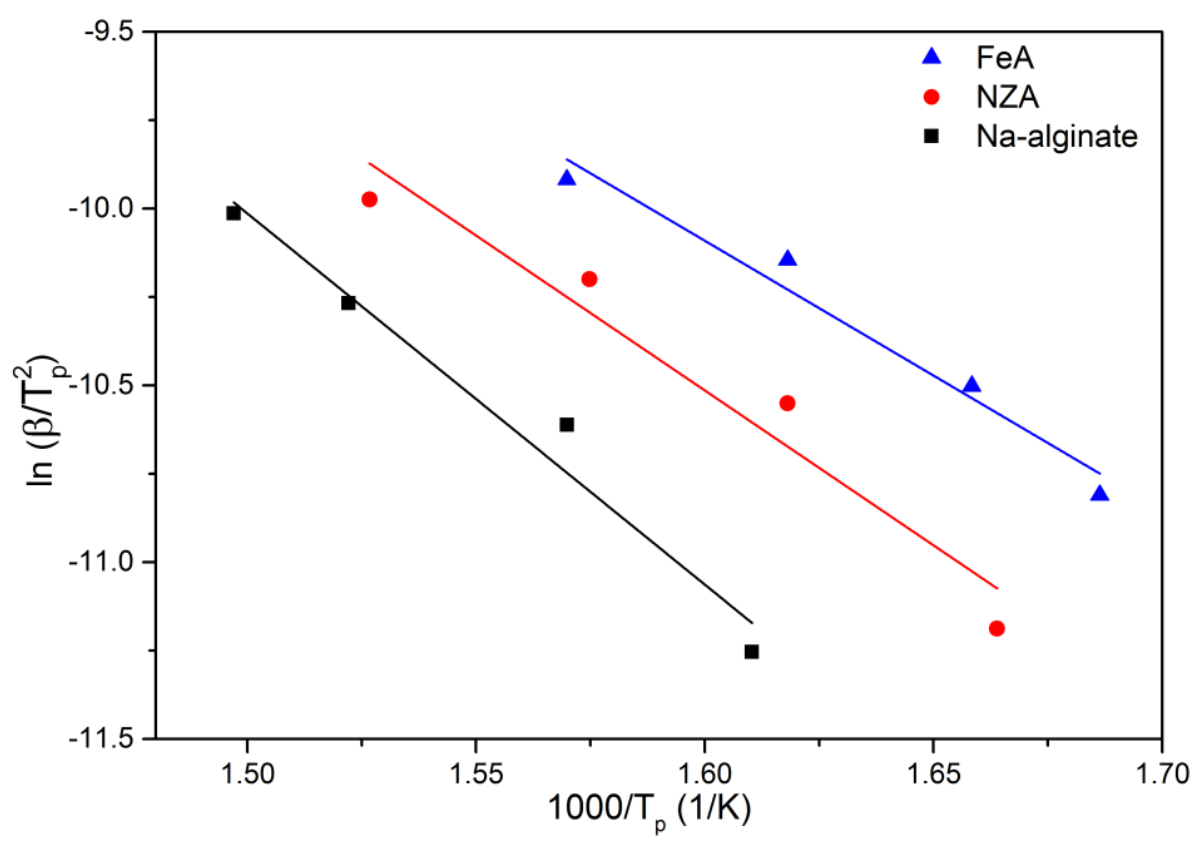

Figure 3 - The plot of $\ln \left(\beta / T_{p}^{2}\right)$ vs $1 / T_{p}$ for the Na-alginate, NZA and FeA

As can be seen from Table 1 the activation energy required for thermal degradation of alginate decreased for composite samples in comparing to the starting $\mathrm{Na}$-alginate. However, lower value of the $E_{a}$ was obtained for FeA than for NZA. The $E_{a}$ value decreased from $87.30 \mathrm{~kJ} / \mathrm{mol}$ for $\mathrm{Na}$-alginate to $72.75 \mathrm{~kJ} / \mathrm{mol}$ for NZA and to $63.35 \mathrm{~kJ} / \mathrm{mol}$ for FeA sample. From that point it can be indicated that both samples, NZA and especially FeA, could be used as additives and may render the materials processing temperature and burning activation energy decrease and possibly allow lowering of the thermal treatment cost.

\section{CONCLUSION}

In this paper thermal degradation of pure alginate and its composites with natural (NZA) and $\mathrm{Fe}$ (III)-modified zeolite (FeA) was investigated. From results of thermogravimetric (TG) and differential thermal analysis (DTA) of the pure alginate it was shown that the highest part of alginate burned in temperature interval from 180 to $500^{\circ} \mathrm{C}(\sim 50 \%)$ where loss of volatile components, rupture of chains and fragmentation of sodium alginate occurs.

Kinetic calculations were performed for most clearly expressed peak at DTA curve in that temperature range (DTA peak at $348^{\circ} \mathrm{C}$ ). Obtained results showed that decomposition shifts to higher temperature as the heating rate increases and also to the lower temperatures for composite samples in comparison with starting alginate sample.
Kinetic analysis shows that the main thermal degradation follows the first order reaction mechanism. Kissinger method was used for determination of the kinetic parameters (preexponential factor and activation energy) from DTA data. Results showed that activation energy for the thermal decomposition of the alginate decreases after addition of the zeolites. Lower values of the activation energy obtained for composite samples indicated that both sample (natural and due to lower value of activation energy, especially $\mathrm{Fe}$ (III)modified zeolite) may be used as additives for thermal degradation of the alginate.

\section{Acknowledgment}

We are thankful to the Ministry of Education, Science and Technological Development of the Republic of Serbia, which has been financing projects TR34013 and ON172018 a part of which is presented in this paper.

\section{REFERENCES}

[1] European Commission, Plastic waste in the environment, Revised final report April 2011 (http://ec.europa.eu/environment/waste/studies/pdf/ plastics.pdf, 1. 12. 2016.)

[2] H.Zhen, Y.Xiaoxu, P.Xi, Z.Yulong, F.Meifen, Z. Qiang (2010) Proceedings of the 17th IAPRI world conference on Packing, Tianjin,China, 406-409.

[3] C.Barrera-Díaz, M.Isabel López Meza, C.Fall, B. Bilyeu, J.Cruz-Olivares (2015) Lead(II) adsorption using allspice-alginate gel biocomposite beads, Sustain. Environ. Res., 25(2), 83-92. 
[4] F.Wang, X.Lu, X.Li (2016) Selective removals of heavy metals $\left(\mathrm{Pb}^{2+}, \mathrm{Cu}^{2+}\right.$, and $\left.\mathrm{Cd}^{2+}\right)$ from wastewater by gelation with alginate for effective metal recovery, J. Hazard. Mater., 306, 75-83.

[5] P.T.Williams, R.Bagri (2004) Hydrocarbon gases and oils from the recycling of polystyrene waste by catalytic pyrolysis, Inter. J. Energy Res., 28(1), 3144.

[6] A.Singhabhandhu, T.Tezuka (2010) The waste-toenergy framework for integrated multi-waste utilization: Waste cooking oil, waste lubricating oil, and waste plastics, Energy, 35(6), 2544-2551.

[7] A.Salmiaton, A.Garforth (2007) Waste catalysts for waste polymer, Waste Management, 27, 1891 1896.

[8] A.Marcilla, A.Gomez, S.Menargeus, J.GarciaMartinez, D.Cazorla-Amoros (2003) Catalytic cracking of ethylene-vinyl acetate copolymers: comparison of different zeolites, J. Anal. Appl. Pyrolysis, 68-69, 495-506.

[9] M.Kragović, A.Daković, M.Marković, A.Petković, J.Petrović, J.Stojanović, J.Milojković (2016) 13th International Conference on Fundamental and Applied Aspects of Physical Chemistry "Physical Chemistry 2016", Belgrade, Serbia, proceedings, Vol 2, p. 699-702.

[10] G.Mustafa, B.Singh, R.S.Kookana (2004) Cadmium adsorption and desorption behaviour on goethite at low equilibrium concentrations: a effects of $\mathrm{pH}$ and index cations, Chemosphere, 57, 1325-1333.

[11] C.S.Jeon, K.Baek, J.K.Park, Y.K.Oh, S.Do Lee (2009) Adsorption characteristics of $\mathrm{As}(\mathrm{V})$ on ironcoated zeolite, J. Hazard. Mater., 163, 804-808.
[12] M.Kragović, A.Daković, Ž.Sekulić, M.Trgo, M. Ugrina, J.Perić, G.D.Gatta (2012) Removal of lead from aqueous solutions by using the natural and Fe(III)-modified zeolite, Appl. Surf. Sci., 258, 36673673.

[13] G.Yan, T.Viraraghavan (2001) Heavy metal removal in a biosorption columnby immobilized M. ruoxii biomass, Bioresour. Technol., 78, 243-249.

[14] C.Xiao, L.Weng, L.Zhang (2002) Improvement of Physical Properties of Crosslinked Alginate and Carboxymethyl Konjac Glucomannan Blend Films, J. Appl. Polym. Sci., 84, 2554-2560.

[15] C.Xiao,Y.Lu, S.S.Gao, L.Zhang (2001) Characterization of Konjac Glucomannan-Gelatin Blend Films, J. Appl. Polym. Sci., 79, 1596-1602.

[16] R.Tripathi, B.Mishra (2012) Development and Evaluation of Sodium Alginate-Polyacrylamide Graft-Co-polymer Based Stomach Targeted Hydrogels of Famotidine, AAPS Pharm. Sci. Tech, 13, 1091-1102.

[17] P.Parhi, A.Ramanan (2006) A.R. Ray, Preparation and characterization of alginate and hydroxyapatitebased biocomposite, J. Appl. Polym. Sci., 102, 5162-5165.

[18] H.E.Kissinger (1956) Variation of peak temperature with heating rate in different rate in differential thermal analysis, J. Res. Nat. Bur. Standards, 57, 217-221.

[19] M.R.Sovizi, S.S.Hajimirsadeghi, B.Naderizadeh (2009) Effect of particle size on thermal decomposition of nitrocellulose, J. Hazard. Mater., $168,1134-1139$.

\section{IZVOD}

\section{KINETIKA TERMIJSKOG RAZLAGANJA KOMPOZITA ALGINATA I ZEOLITA}

U ovom radu ispitivana je upotreba prirodnog i Fe(III)-modifikovanog zeolite kao aditiva alginatu $u$ cilju poboljšanja njegovih termijskih i pirolitičkih osobina. Za tu namenu korišćeni su uzorci prirodnog (PZA) i Fe(III)-modifikovanog zeolita prekrivenih alginatom (FeA). Sagorevanje uzoraka praćeno je termijskim analitičkim tehnikama, diferencijalnom termijskom analizom (DTA) $i$ termogravimetrijskom analizom (TGA). Uzorci su zagrevani u temperaturskom intervalu od 25 do $1000^{\circ} \mathrm{C}$ pri različitim brzinama zagrevanja (od 5 do $20^{\circ} \mathrm{C}$ ). Na osnovu eksperimentalnih rezultata, merenjem gubitka mase, termijsko razlaganje natrijum alginata se jasno može podeliti u nekoliko koraka. Na osnovu kinetičkog modela pseudo-prvog reda određeni su kinetički parametri (aktivaciona energija i pred eksponencijalni faktor) koji se odnose na temperaturski interval od 180 do $500^{\circ} \mathrm{C}$. Dobijeni rezultati su pokazali da upotrebljeni zeoliti utiču na termijske osobine alginata kao i da smanjuju aktivacionu energiju potrebnu za njegovu pirolizu sa $87,30 \mathrm{~kJ} / \mathrm{mol}$ za čist alginat na $72,75 \mathrm{~kJ} / \mathrm{mol}$ za PZA i $63,35 \mathrm{~kJ} / \mathrm{mol}$ za FeA. Ova ispitivanja mogu biti korisna za bolje razumevanje termijske stabilnosti alginatnih biokompozita i mogu dati informacije važne za termijske procese biorazgrađujućih materijala.

Ključne reči: Na-alginat, prirodni zeolit, Fe(III)-modifikovani zeolit, kompozit, termogravimetrijska i diferencijalna termijska analiza, kinetika termijske degradacije.

\section{Naučni rad}

Rad primljen: 12. 10. 2016.

Rad prihvaćen: 09. 11. 2016.

Rad je dostupan na sajtu: www.idk.org.rs/casopis 